\title{
High Thermal Conductivity Resin Systems for High Energy Physics Magnets
}

\section{Cooperative Research and Development Agreement Final Report}

\section{CRADA Number: FRA-2019-0033}

\section{Fermilab Technical Contact: Steven T. Krave}

Summary Report

15 June 2021 


\section{NOTICE}

This report was prepared as an account of work sponsored by an agency of the United States government. Neither the United States government nor any agency thereof, nor any of their employees, makes any warranty, express or implied, or assumes any legal liability or responsibility for the accuracy, completeness, or usefulness of any information, apparatus, product, or process disclosed, or represents that its use would not infringe privately owned rights. Reference herein to any specific commercial product, process, or service by trade name, trademark, manufacturer, or otherwise does not necessarily constitute or imply its endorsement, recommendation, or favoring by the United States government or any agency thereof. The views and opinions of authors expressed herein do not necessarily state or reflect those of the United States government or any agency thereof.

Available electronically at http://www.osti.gov/

Available for a processing fee to U.S. Department of Energy and its contractors, in paper, from:

U.S. Department of Energy

Office of Scientific and Technical Information

P.O. Box 62

Oak Ridge, TN 37831-0062

phone: 865.576.8401

fax: 865.576 .5728

email: mailto:reports@osti.gov

Available for sale to the public, in paper, from:

U.S. Department of Commerce

National Technical Information Service

5301 Shawnee Rd

Alexandria, VA 22312

phone: 800.553 .6847 or $703-605-6000$

fax: 703.605.6900

email: orders@ntis.gov

online ordering: http://www.ntis.gov/ 
In accordance with Requirements set forth in Article XI.A(3) of the CRADA document, this document is the final CRADA report, including a list of Subject Inventions, to be forwarded to the Office of Science and Technical Information as part of the commitment to the public to demonstrate results of federally funded research.

CRADA number: $\quad$ FRA-2019-0033

CRADA Title: $\quad$ High Thermal Conductivity Resin Systems for High Energy Physics Magnets

Parties to the Agreement: Composite Technology Development, Inc. (CTD) and Fermi Research Alliance, LLC (FRA)

Sponsoring DOE Program Office(s): Office of Science - High Energy Physics

\title{
DOE Funding Commitment Table:
}

Funding was provided by CTD to FRA as a subaward under SBIR/STTR Award No. DESC0018701. No additional DOE funding was committed by FRA.

\begin{abstract}
CRADA work:
In $\mathrm{Nb}_{3} \mathrm{Sn}$ superconducting magnets, the cable and insulation system dominate the behavior of a completed magnet, with contributions to the mechanical behavior from the stiff, brittle components of the superconductor, the soft annealed copper stabilizer, and the properties of the composite insulation system. As these components are closely integrated on a small scale, it is of value to explore the properties of the entire system at a larger scale, to enable practical magnet design.

Subscale composite testing (Stack Testing) has been used extensively to study the bulk material properties of the magnet composite structure. Small samples that mimic the fabrication process of magnets are fabricated and tested to qualify and characterize magnet insulation systems for use in future magnet projects as well as to better inform magnet designers about means for assembly and general handling processes.
\end{abstract}

Subscale composite samples will be fabricated and characterized using various novel resins to work to improve magnet performance. New resin systems will be screened to allow for down selection to one or more highly promising resin systems. The work performed under this agreement at Fermilab will feed via CTD into the fabrication of subscale magnets at Lawrence Berkeley National Laboratory (LBNL) for verification of magnet performance. 


\section{Summary of Research Results:}

In collaboration with Composite Technology Development, several candidate resins were evaluated for mechanical properties in Nb3sn Composites at room temperature as well as cryogenic temperature. Three resin systems, CTD 153, CTD 155, and CTD 701x, were evaluated and compared to CTD 101k. Evaluations at FNAL included 4-stack short beam testing, Ten stack modulus measurement, thermal shock sample testing and general observations of resin processing during sample fabrication. Of the three systems, the CTD 701x system shows the most promising results as a general purpose resin as it has extremely low viscosity, high toughness, extreme thermal shock resistance and otherwise typical behavior in a ten stack configuration. Initial formulations with this resin system by CTD were less than ideal when loaded with thermally conductive fillers, but the novelty of the resin warrants further investigation.

Additional work with the 701 system is now currently underway at LBNL as part of an SBIR Phase II listed above as well as the Paul Scherrer Institute and CERN as a result of the initial interest in this system.

To better fulfill the thermally conductive portion of this topic, the CTD 155 system has been selected for modifications using nano-fillers and has shown promise at CTD for initial testing.

A more detailed description of the resin testing and results can be found in the report below.

\section{Related Reports, Publications, and Presentations:}

S. Krave, T. Shen and A. Haight, "Exploring New Resin Systems for Nb3Sn Accelerator Magnets," in IEEE Transactions on Applied Superconductivity, vol. 31, no. 5, pp. 1-4, Aug. 2021, Art no. 4001904, doi: 10.1109/TASC.2021.3059607.

\section{Subject Inventions listing:}

N/A

Report Date: 15 June 2021

Technical Contact at Fermilab: Steven T. Krave

Partner POC Name and Email Address: Andrea Haight, andrea.haight@ctd-materials.com

This document contains NO confidential, protectable or proprietary information. 